\title{
DETERMINATION OF WATER IN SILICATE ROCK SAMPLES BY COMBUSTION AND INFRARED ABSORPTION
}

\author{
RISTO J. SAIKKONEN
}

\begin{abstract}
SAIKKONEN, RISTO J., 1990. Determination of water in silicate rock samples by combustion and infrared absorption. Bull. Geol. Soc. Finland 62, Part 1, 71-77.

An infrared absorption method is described for the determination of water in powdered silicate rock samples. For determination of the total water $\left(\mathrm{H}_{2} \mathrm{OTot}\right)$, airdried samples were combusted at $1100^{\circ} \mathrm{C}$ without a flux and the evolved water was passed through an IR cell for the measurement. Essential water $\left(\mathrm{H}_{2} \mathrm{O}^{+}\right)$, was determined in a similar way but from samples dried at $110^{\circ} \mathrm{C}$. For determination of non-essential water $\left(\mathrm{H}_{2} \mathrm{O}^{-}\right)$, air-dried samples were heated at $110^{\circ} \mathrm{C}$.

Results $\left(\mathrm{H}_{2} \mathrm{O}\right.$ tot, $\mathrm{H}_{2} \mathrm{O}^{+}$and $\left.\mathrm{H}_{2} \mathrm{O}^{-}\right)$for 13 in-house reference rock samples (maximum grain size about $80 \mathrm{mesh}$ ) and eight international geological reference samples (maximum grain size about 200 mesh) agreed well with the results obtained by conventional methods, and the results obtained for the international samples compared well with published data. The precision of the IR absorption method is good (relative standard deviation $<3 \%$ ) if the water content of the sample is more than $0.5 \%$ and poorer if the content is less than $0.5 \%$. The practical detection limit is about $0.01 \% \mathrm{H}_{2} \mathrm{O}$. The new method is more rapid than the conventional methods.
\end{abstract}

Key words: chemical analysis, infrared spectroscopy, water, abundance, silicate rocks, samples.

Risto J. Saikkonen: Geological Survey of Finland. SF-02150 Espoo, Finland.

\section{Introduction}

In the total analysis of silicate rocks water cannot be determined by the common instrumental techniques such as atomic absorption, X-ray fluorescence or plasma emission. The determination of water with high accuracy is difficult and the method is often complicated and slow compared with analytical methods for other components. Non-essential water $\left(\mathrm{H}_{2} \mathrm{O}^{+}\right)$, or free moisture, is held by surface forces such as adsorption and capillarity and its presence is not essential to the characterization of the sample. It tends to be related more to physical properties and sample treatment (humidity, grain size etc.) than to composition. Normally, the nonessential water is determined as the loss in weight of an air-dried sample after heating at 105$110^{\circ} \mathrm{C}$ (Johnson and Maxwell 1981; Jeffery and Hutchison 1983). Essential water $\left(\mathrm{H}_{2} \mathrm{O}^{+}\right)$, also known as water of crystallization, bound water or combined water, is present in regular atomic arrangement in the molecular or crystal structure. In many silicate rocks (e.g. basaltic glasses) hydrogen is present mainly in the form of water (Potts 1987). Elemental $\mathrm{H}$ occurs in metamorphic rocks and in sedimentary rocks (Jeffery and Hutchison 1983). The hydroxide group $(\mathrm{OH})$, is important in clays (Volborth 1969). The water in fluid inclusions in minerals is non-essential water, 
but in common minerals it is not released from the inclusions by heating at low temperatures (below $110^{\circ} \mathrm{C}$ ). The role and classification of hydrogen and water in silicate rocks and minerals have been discussed in detail by Hillebrand et al. 1953; Mitchell 1961; Baur 1978 and Pyper 1985.

Total water is non-essential water plus essential water $\left(\mathrm{H}_{2} \mathrm{OTot}=\mathrm{H}_{2} \mathrm{O}^{-}+\mathrm{H}_{2} \mathrm{O}^{+}\right)$. The existing methods for the determination of $\mathrm{H} 2 \mathrm{OT}$ ot and $\mathrm{H}_{2} \mathrm{O}^{+}$generally involve the combustion of an air-dried sample and a sample dried at $110^{\circ} \mathrm{C}$ with or without a flux. Most rocks will release all water without a flux if the combustion temperature is high enough (Skinner et al. 1981; Potts 1987). Some minerals do not release all their water without a flux unless temperatures exceed $1100^{\circ} \mathrm{C}$, e.g. talc, topaz, staurolite, chondrodite, titanite, epidote and cordierite (Riley 1958; Maxwell 1968; Potts 1987). A flux is also necessary for mica and for rocks having a fairly high mica content (Kuzuhisa 1979). The evolved water is usually determined by gravimetric, titrimetric, thermal conductivity or infrared spectrometric methods. The classic gravimetric methods, including the Penfield method and its modifications, are slow and require close attention of the analyst during the determination (Penfield 1894; Peck 1964; Maxwell 1968; Donaldson 1973; DeLong and Lyman 1981). Titrimetric methods like the Karl-Fischer titration give fairly good results but are slow (Westrich 1987; Kuzuhisa 1979; Abbey 1979; Turek et al. 1976; Troll and Farzaneh 1978). Thermal conductivity methods (e.g. C-H-N elemental analyzer) are rapid, but the requirement for a $25-\mathrm{mg}$ portion of sample could result in loss of sample representativiness (Skinner et al. 1981; Din and Jones 1978). Direct determination of essential water in a variety of rocks by infrared absorption using $\mathrm{O}-\mathrm{H}$ stretching vibrations has been demonstrated to be useful when only a small amount of sample (a few milligrammes) is available (Augott and Marchall 1969; Breger and Chandler 1969). A method for the combined determination of water, carbon and sulphur by volatilization and non-dispersive in- frared absorptiometry has been described by Bouvier and Abbey (1980), who claim that their procedure is more rapid than most similar methods.

In this study the new RMC -100 moisture analyzer (Leco Corporation) of the Geological Survey of Finland was used to determine the content of water $\left(\mathrm{H}_{2} \mathrm{OTot}, \mathrm{H}_{2} \mathrm{O}^{+}\right.$and $\left.\mathrm{H}_{2} \mathrm{O}^{-}\right)$in 13 in-house reference rock samples (maximum grain size about 80 mesh, Backman and Liukkonen 1990) and eight international geological reference samples (maximum grain size about 200 mesh, Govindaraju 1980; Abbey 1983; Flanagan 1984). The results are compared with results obtained by the Penfield method $\left(\mathrm{H}_{2} \mathrm{Otot}, \mathrm{H}_{2} \mathrm{O}^{+}\right)$and the classical gravimetric method $\left(\mathrm{H}_{2} \mathrm{O}^{-}\right)$, and in the case of the international geological reference samples also with published data. The purpose of the study was to develop a rapid and satisfactory method for complete rock analysis.

\section{Experimental}

\section{Conventional methods}

Non-essential water, $\mathrm{H}_{2} \mathrm{O}^{-}$, was determined by gravimetric method from the loss in weight of air-dried samples heated at $110^{\circ} \mathrm{C}$. The method was as follows: About $0.5 \mathrm{~g}$ of powdered sample was accurately weighed and transferred to a clean $30-\mathrm{ml}$ platinum crucible. The crucible and contained sample were weighed, after which the crucible was placed in an oven and heated at $110^{\circ} \mathrm{C}$ for at least $2 \mathrm{hr}$. The crucible was transferred to a desiccator and allowed to cool for 30 min before weighing. Heating, cooling and weighing were repeated until no further loss in weight occurred.

The total water, H2Otot, and the essential water, $\mathrm{H}_{2} \mathrm{O}^{+}$, were determined by the modified Penfield method (Danielsson and Saikkonen 1985; Maxwell 1968). The method was as follows: $0.5 \mathrm{~g}$ of air-dried powdered sample or sample dried at $110^{\circ} \mathrm{C}$ and $1 \mathrm{~g}$ of lead oxide were weighed and transferred into the sample bulb at the end 
Fig. 1. RMC-100 rapid moisture analyzer.

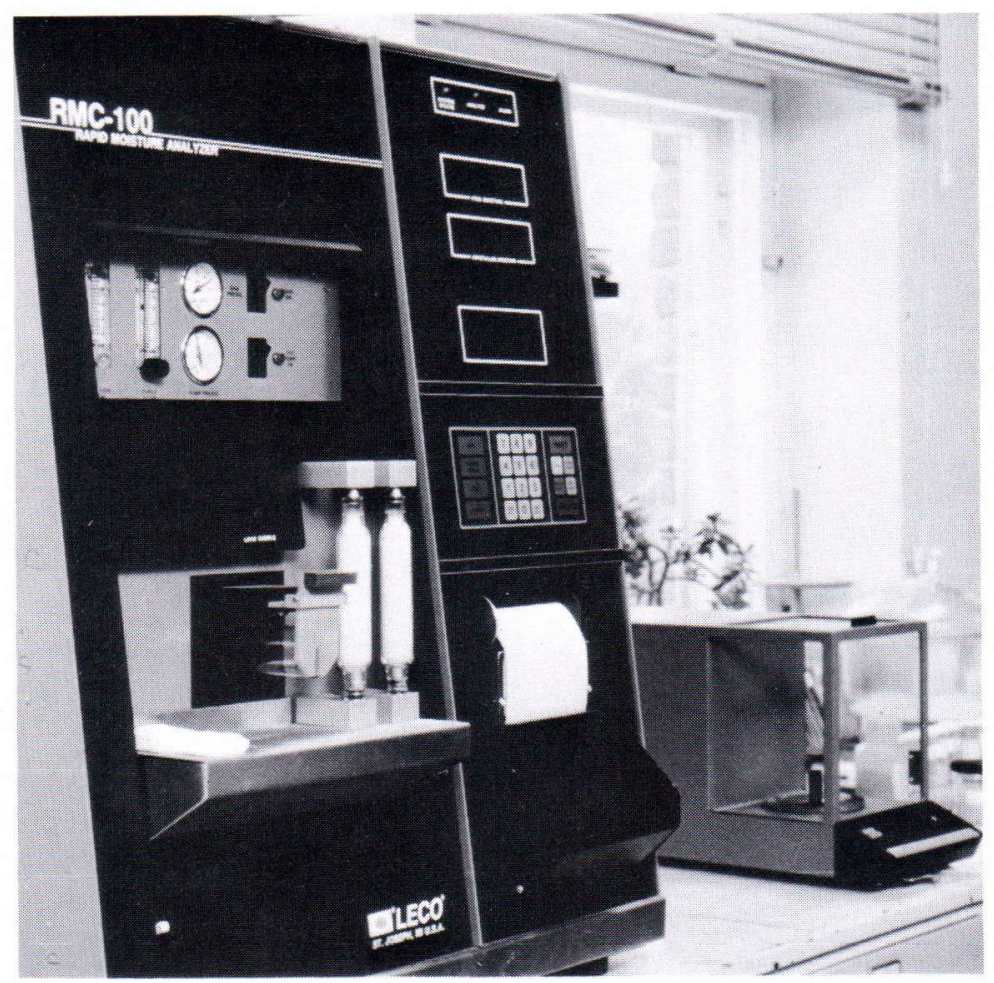

of a Penfield tube. The water collection bulbs of the Penfield tube were wrapped with cold wet paper. The sample bulb was heated over a Bunsen burner for about $20 \mathrm{~min}$, while the water evolved condensed into the collection bulbs. The Penfield tube with the contained water was weighed, after which the tube was dried and weighed. The weight difference is the content of the total water or essential water, depending on whether the sample was air-dried or dried at $110^{\circ} \mathrm{C}$.

\section{Infrared absorption method}

\section{Description of apparatus}

The RMC-100 is a microprocessor-based instrument (Fig.1) for determining the non-essential, essential and total water in rock samples and in a variety of other materials. For measurement of the non-essential water the sample is loaded into the reaction chamber at the loading temperature. The water, driven from the sample with nitrogen carrier gas, passes through the infrared (IR) cell, where the water absorbs energy at a specific wavelength within the IR spectrum. This wavelength is selectively passed though a filter to an IR sensor where the concentration of water is detected as an energy level. The energy level is then amplified, rectified and converted to a digital signal. The data are sampled twice a second, linear corrections are made and the data are integrated to find the concentration of the water. The results are displayed as weight percent.

For the measurement of the essential water and the total water, the high-power-ramping furnace heats to a preset high temperature driving the essential water or the total water from the sample. The concentrations of the essential and total water are calculated in the same manner as the 
concentration of the non-essential water. When analysis is done in the rapid mode the loading temperature can be set to a maximum of $500^{\circ} \mathrm{C}$ and the high temperature up to $1200^{\circ} \mathrm{C}$. This optimizes sample throughput.

Two types of plots can be selected for the automatic print out of results. Moisture loss plots show percentage moisture of the sample on the vertical axis and time in seconds on the horizontal axis. A temperature line indicates temperature in respect to time. Intensity plots show the concentration of water in the IR cell in computer counts on the vertical axis, time on the horizontal axis and the temperature line in respect to time.

The electronic balance is interfaced with the instrument. Ceramic crucible boats (model $781-335)$ are used to hold the samples. The recommended carrier gas is $99 \%$ pure nitrogen.

\section{Procedure used}

The RMC-100 instrument was operated as specified in the manufacturer's manual. The instrument was calibrated on the basis of several determinations of the geological reference samples: BHVO-1 Basalt, G-2 Granite, SDC-1 Mica Schist, PCC-1 Peridotite and UB-N Serpentine (Abbey 1983). Air-dried powdered samples were used for the determination of $\mathrm{H}_{2} \mathrm{O}^{-}$and $\mathrm{H}_{2} \mathrm{OT}$ tot and samples dried at $110^{\circ} \mathrm{C}$ for the determination of $\mathrm{H}_{2} \mathrm{O}^{+}$. Both $\mathrm{H}_{2} \mathrm{OTot}$ and $\mathrm{H}_{2} \mathrm{O}^{+}$were measured in the rapid mode where the loading temperature was $500^{\circ} \mathrm{C}$. Briefly the procedure was as follows: About $0.5 \mathrm{~g}$ of the powdered, air-dried sample or sample dried at $110 \mathrm{oC}$ was accurately weighed into a clean dry ceramic crucible boat, with the powder spread evenly over the bottom of the boat. The boat was then slid into the reaction chamber (temperature $110^{\circ} \mathrm{C}$ or $500^{\circ} \mathrm{C}$ ) using the sample puller. The free moisture, $\mathrm{H}_{2} \mathrm{O}^{-}$, was driven off at $110^{\circ} \mathrm{C}$ and passed with nitrogen gas through the IR cell. In the rapid mode used for the measurement of combined and total water, the temperature was quickly raised from $500^{\circ} \mathrm{C}$ to $1100^{\circ} \mathrm{C}$, and the water driven from the sample with nitrogen gas was again passed through the IR cell. The result was displayed as weight percent. The print out was taken in the long format and with data shown in the form of intensity plots.

\section{Results and discussion}

\section{Precision and accuracy}

The contents of the total, essential and nonessential water in thirteen in-house rock samples were determined by infrared absorption method. The total water was also determined by the modified Penfield method, and the free moisture by the gravimetric method. The results are shown in Tables 1 and 3. In addition, eight international geological reference samples were analyzed by the same methods. These results, along with the published results, are shown in Table 2 . The precision of the infrared absorption method was evaluated from the results of 3-20 determinations of the in-house and international reference samples (Tables 1-3). The coefficients of variation (CV), followed reasonably well the general trend of small coefficients for samples with high concentrations and large coefficients for samples with low concentrations of the constituents.

The precision of the Penfield method and the gravimetric method was calculated from the results of 2-13 analyses of the in-house and international reference samples (Tables $1-3$ ). The coefficients of variation were of the same magnitude as for the infrared method.

The values of replicate blank analysis obtained by combusting 20 empty, dry crucible boats were as follows: 17 times $0.000 \%$, twice $0.001 \%$ and once $0.006 \% \mathrm{H}_{2} \mathrm{O}$. The mean was $0.0004 \%$ $\mathrm{H}_{2} \mathrm{O}$, and the standard deviation (s) was $0.0014 \%$ $\mathrm{H}_{2} \mathrm{O}$. The detection limit, defined as 3 times the standard deviation (3s) of the blank value, was $0.004 \% \mathrm{H}_{2} \mathrm{O}$. The practical detection limit using a sample weight of $0.5 \mathrm{~g}$ was approximately $0.01 \% \mathrm{H}_{2} \mathrm{O}$. 
Table 1. Comparison of total water $\left(\mathrm{H}_{2} \mathrm{OTot}\right)$ and essential water $\left(\mathrm{H}_{2} \mathrm{O}^{+}\right)$determinations for in-house reference rock samples by the infrared absorption method and by the modified Penfield method. $\mathrm{N}=$ number of replicate determinations, $\mathrm{CV}=$ coefficient of variation.

\begin{tabular}{|c|c|c|c|c|c|c|c|c|}
\hline \multirow[t]{2}{*}{ Sample } & \multicolumn{4}{|c|}{ Infrared absorption method } & \multicolumn{4}{|c|}{ Penfield method } \\
\hline & $\mathrm{H}_{2} \mathrm{OTot} \%$ & $\mathrm{~N}$ & $\mathrm{CV} \%$ & $\mathrm{H}_{2} \mathrm{O}+\% *$ & $\mathrm{H}_{2} \mathrm{OTot} \%$ & $\mathrm{~N}$ & $\mathrm{CV} \%$ & $\mathrm{H}_{2} \mathrm{O}+\% * *$ \\
\hline RS 11 Gabbro & 1.63 & 15 & 2.0 & 1.52 & 1.55 & 7 & 2.6 & 1.51 \\
\hline \multirow{2}{*}{$\begin{array}{c}\text { RS } 31 \text { Rapakivi } \\
\text { granite }\end{array}$} & & & & & & & & \\
\hline & 0.62 & 10 & 2.4 & 0.47 & 0.50 & 7 & 5.1 & 0,47 \\
\hline RS 51 Quartzite & 0.27 & 10 & 4.8 & 0.24 & 0.26 & 1 & - & 0.26 \\
\hline RS 61 Trondjemite & 0.50 & 7 & 2.9 & 0.42 & 0.54 & 1 & - & 0.54 \\
\hline RS 71 Diabase & 0.88 & 8 & 1.4 & 0.70 & 0.83 & 2 & 8.5 & 0.70 \\
\hline RS 81 Granite & 0.45 & 8 & 2.2 & 0.35 & 0.48 & 1 & - & 0.44 \\
\hline RS 91 Phyllite & 3.94 & 10 & 0.5 & 3.65 & 3.94 & 2 & 0.2 & 3.75 \\
\hline RS 101 Diorite & 0.71 & 8 & 1.0 & 0.57 & 0.70 & 3 & 11.0 & .61 \\
\hline \multicolumn{9}{|l|}{ RS 121 Peridotitic } \\
\hline komatiite & 7.58 & 10 & 1.4 & 7.30 & 7.21 & 7 & 1.0 & 7.04 \\
\hline \multicolumn{9}{|l|}{ RS 131 Basaltic } \\
\hline komatiite & 6.24 & 10 & 1.0 & 6.08 & 6.62 & 6 & 1.4 & 6.53 \\
\hline RS 211 Serpentinite & 13.76 & 15 & 1.6 & 13.04 & 13.46 & 7 & 1.0 & 12.70 \\
\hline RS 212 Serpentinite & 13.73 & 6 & 0.9 & 13.02 & 13.22 & 2 & 0.1 & 12.51 \\
\hline
\end{tabular}

* $\quad \mathrm{N}=3-4$ and the coefficients of variation, $\mathrm{CV}$, are approximately same as in the data for $\mathrm{H}_{2} \mathrm{OTot}$ by IR absorption method.

** Calculated: $\mathrm{H}_{2} \mathrm{OTot}-\mathrm{H}_{2} \mathrm{O}^{-}=\mathrm{H}_{2} \mathrm{O}^{+}$(see Table 3).

The results $\left(\mathrm{H}_{2} \mathrm{OTot}, \mathrm{H}_{2} \mathrm{O}^{+}\right.$and $\left.\mathrm{H}_{2} \mathrm{O}^{-}\right)$determined by the IR absorption method and by the conventional methods were in good agreement (Tables 1-3). The IR absorption method gave good results for most of the international geological samples relative to published values, but too low values for the samples MA-N and ES681-1 (Table 2). The information obtained from the intensity plots showed that the temperature, $1100^{\circ} \mathrm{C}$, was high enough for all samples in this study.

\section{General remarks}

The fine grinding of minerals and rocks may lead to either an increase or a decrease in total water content. An increase is the result of the subdivision of grains and development of a greater

Table 2. $\mathrm{H}_{2} \mathrm{O}^{+}$content in weight percent for some international geological reference samples determined by infrared absorption method (this study) and by the modified Penfield method (earlier at the Geological Survey of Finland). $\mathrm{n}=$ number of determinations during three days, $\mathrm{N}=$ number of replicate determinations, $\mathrm{CV}=$ coefficient of variation. $\mathrm{D}=$ Danielsson and Saikkonen 1985, $\mathrm{G}=$ Govindaraju 1980, $\mathrm{A}=$ Abbey 1979, Ab = Abbey 1983.

\begin{tabular}{|c|c|c|c|c|c|c|c|c|}
\hline \multirow[t]{2}{*}{ Sample } & & \multicolumn{3}{|c|}{ Infrared absorption method } & \multicolumn{3}{|c|}{ Modified Penfield method } & \multirow{2}{*}{$\begin{array}{l}\text { Liter.val. } \\
\mathrm{H}_{2} \mathrm{O}^{+} \%\end{array}$} \\
\hline & & $\mathrm{H}_{2} \mathrm{O}+\Phi_{0}$ & $\mathrm{n}$ & $\mathrm{CV} \%$ & $\mathrm{H}_{2} \mathrm{O}+\%$ & $\mathrm{~N}$ & $\mathrm{CV} \%$ & \\
\hline BIR-1 & Icelandic basalt & 0.09 & 3 & 8 & $0.06 \mathrm{D}$ & 6 & 9 & $0.09 \mathrm{D}$ \\
\hline W-2 & Centerville diabase & 0.59 & 3 & 3 & $0.58 \mathrm{D}$ & 6 & 4 & $0.55 \mathrm{D}$ \\
\hline DNC-1 & Diabase & 0.76 & 3 & 2 & $0.60 \mathrm{D}$ & 6 & 4 & $0.73 \mathrm{D}$ \\
\hline MA-N & Granite & 0.92 & 3 & 4 & $0.93 \mathrm{G}$ & 1 & - & $1.08 \mathrm{G}$ \\
\hline AN-G & Anorthosite & 0.63 & 3 & 4 & $0.61 \mathrm{G}$ & 1 & - & $0.61 \mathrm{G}$ \\
\hline BE-N & Basalt & 2.25 & 3 & 3 & $2.14 \mathrm{G}$ & 1 & - & $2.25 \mathrm{G}$ \\
\hline MRG-1 & Gabbro & 0.98 & 3 & 3 & $1.07 \mathrm{~A}$ & 1 & - & $0.98 \mathrm{~A}$ \\
\hline ES-681-1 & Iron ore & 9.93 & 3 & 3 & 9.92 & 10 & 2 & $10.4 \mathrm{Ab}$ \\
\hline
\end{tabular}


Table 3. Comparison of free moisture $\left(\mathrm{H}_{2} \mathrm{O}^{-}\right)$determinations for in-house reference samples made by the infrared absorption method and by the gravimetric method. $\mathrm{N}=$ number of determinations, $\mathrm{H}_{2} \mathrm{O}-\% \pm$ sd $=$ mean $\% \pm$ standard deviation.

\begin{tabular}{|c|c|c|c|c|c|}
\hline \multirow[t]{2}{*}{ Sample } & \multirow{3}{*}{$\begin{array}{l}\text { Sampling site } \\
\text { Hyvinkää }\end{array}$} & \multicolumn{2}{|c|}{ Infrared absorption method } & \multicolumn{2}{|c|}{ Gravimetric method } \\
\hline & & $\mathrm{H}_{2} \mathrm{O}-\% \pm \mathrm{sd}$ & $\mathrm{N}$ & $\mathrm{H}_{2} \mathrm{O}-\% \pm \mathrm{sd}$ & $\mathrm{N}$ \\
\hline RS 11 Gabbro & & $0.03 \pm 0.01$ & 20 & $0.04 \pm 0.01$ & 7 \\
\hline \multirow{2}{*}{\multicolumn{6}{|c|}{$\begin{array}{c}\text { RS } 31 \text { Rapakivi } \\
\text { granite }\end{array}$}} \\
\hline & Uhlu & $0.03 \pm 0.02$ & 3 & $0.03 \pm 0.01$ & 2 \\
\hline RS 51 Quartzite & Nilsiä & $0.00 \pm 0.01$ & 3 & $0.00 \pm 0.01$ & 2 \\
\hline RS 61 Trondjemite & Uusikaupunki & $0.01 \pm 0.01$ & 3 & $0.01 \pm 0.01$ & 2 \\
\hline RS 71 Diabase & Kuivanen & $0.13 \pm 0.03$ & 3 & $0.13 \pm 0.03$ & 2 \\
\hline RS 81 Granite & Kuru & $0.04 \pm 0.02$ & 3 & $0.04 \pm 0.02$ & 2 \\
\hline RS 91 Phyllite & Karunki & $0.30 \pm 0.04$ & 3 & $0.23 \pm 0.06$ & 2 \\
\hline RS 101 Diorite & Huopana & $0.10 \pm 0.03$ & 3 & $0.05 \pm 0.01$ & 2 \\
\hline RS 111 Granite & Väkkärä & $0.05 \pm 0.02$ & 3 & $0.03 \pm 0.01$ & 2 \\
\hline \multicolumn{6}{|l|}{ RS 121 Peridotitic. } \\
\hline komatite & Moskuvaara & $0.33 \pm 0.03$ & 10 & $0.17 \pm 0.02$ & 7 \\
\hline \multicolumn{6}{|l|}{ RS 131 Basaltic } \\
\hline komatite & Sattasvaara & $0.17 \pm 0.03$ & 10 & $0.09 \pm 0.01$ & 6 \\
\hline RS 211 Serpentinite & Luikonlahti & $0.78 \pm 0.05$ & 10 & $0.76 \pm 0.06$ & 7 \\
\hline RS 212 Serpentinite & Luikonlahti & $0.66 \pm 0.04$ & 3 & $0.71 \pm 0.07$ & 2 \\
\hline
\end{tabular}

surface area upon which water can be adsorbed or otherwise held. A decrease is mostly due to decomposition caused by local heating or it may also occur through the evaporation of water of fluid inclusions when grinding exposes them (Hillebrand et al. 1953; Maxwell 1968). Heating at $110^{\circ} \mathrm{C}$ will drive off most of the non-essential water, although temperatures considerably above this are necessary on occasion. The division into "minus» and "plus» water is partially an arbitrary one, but the determination of the nonessential water is important in providing the petrologist with a means for reducing analyses to a common dry-weight basis.

The infrared absorption method described has several advantages. Once the RMC-100 instrument is set up and has stabilized, the operation is simple and unvarying. The method is also rapid. In the rapid mode, determinations of $\mathrm{H}_{2} \mathrm{OT}$ tot and $\mathrm{H}_{2} \mathrm{O}^{+}$in most samples can be completed in five to ten minutes. Forty determinations of $\mathrm{H}_{2} \mathrm{OT}$ Tot or $\mathrm{H}_{2} \mathrm{O}^{+}$can be made by an analyst during one working day, compared with 15 determinations with the Penfield method. Alternatively 30 determinations of $\mathrm{H}_{2} \mathrm{OTot}=$ $\left(\mathrm{H}_{2} \mathrm{O}^{-}+\mathrm{H}_{2} \mathrm{O}^{+}\right)$can be made daily, compared with 10 determinations with the conventional methods. Sample calibration is required and standards such as in-house reference samples need to be analyzed periodically to confirm accuracy and proper operation of the instrument. The method is suitable for determining water in silicate rocks at level 0.01 to $13 \%$ if the sample weight is $0.5 \mathrm{~g}$. Although a sample size of $0.5 \mathrm{~g}$ was used in this work, sizes down to $0.100 \mathrm{~g}$ are suitable for materials with high water content and sizes up to $2.000 \mathrm{~g}$ for materials with low water content.

Acknowledgements. I wish to thank Dr. Kari Kinnunen, Mr Esko Kontas and Mr Pentti Noras for critically reading the manuscript. I am also indebted to Mr Juhani Oinonen for assistance in the measurements and to Mrs. Kathleen Ahonen for correcting the English. 


\section{References}

Abbey, S., 1979. Reference Materials - Rock Samples SY-2, SY-3, MRG-1. CANMET Report 79-35.

Abbey, S., 1983. Studies in "standard samples» of silicate rocks and minerals, 1969-1982. Geol. Surv. Canada, Paper 83-15.

Augott, J.N. \& Marshall, M., 1969. Quantitative determination of water in granites by infra-red analysis. Mineral. Mag. 37, 256.

Backman, C. \& Liukkonen, J., 1990. Sampling and data evaluation of 13 rock samples for internal quality control. Geostand. Newslett. Special Issue, GEOANALYSIS 90. (In press).

Baur, W.H., 1978. Hydrogen. Handbook of Geochemistry II/1. Springer-Verlag. Berlin. 1.

Bouvier, J. \& Abbey, S., 1980. Simultaneous determination of water, carbon dioxide and sulfur in rocks by volatilization and non-dispersive infrared absorptiometry. Can. J. Spectroscopy 25, 126-132.

Breger, I.A. \& Chandler, J.D., 1969. Determination of fixed $\mathrm{H}_{2} \mathrm{O}$ in rocks by infrared absorption. Anal. Chem. 41, 506.

Danielsson, $R$. \& Saikkonen, R., 1985. Chemical analysis of USGS-W-2, USGS-DNC-1 and USGS-BIR-1 standard rocks. Geol. Surv. Finland, Rept. Invest. 70, Espoo.

De Long, S.E. \& Lyman, P., 1982. Water capture in rapid silicate analysis. Chem. Geol. 35, 173-176.

Din, V.K. \& Jones G.C., 1978. The determination of total carbon and combined water in silicates using a C,H.N elemental analyzer. Chem. Geol. 23, 347-352.

Flanagan, F.J., 1984. Three USGS Mafic Rock Reference Samples, W-2, DNC-1, and BIR-1. U.S. Geol. Surv. Bull. 1623.

Govindaraju, K., 1980. Report (1980) on Three GIT-IWG Rock Reference Samples: Anorthosite from Greenland, AN-G; Basalte d'Essey-la-Cote BE-N; Granite de Beauvoir, MA-N, Geostand. Newslett. 4, 49-138.

Groves, A.W., 1951. Silicate Analysis, 2nd ed., George Allen and Unwin, London, 95-104.
Hillebrand, W.F.; Lundell, G.E.F.; Bright, H.A., \& Hoffman, J.I., 1953. Applied Inorganic Analysis, 2nd ed., New York: John Wiley and Sons, 814-835.

Jeffery, P.G. \& Hutchison, D., 1983. Chemical Methods of Rock Analysis, 3rd ed., Pergamon Press, Oxford, 182-190.

Johnson, W.M. \& Maxwell J.A., 1981. Rock and Mineral Analysis, 2nd ed., New York: John Wiley and Sons, $123-135$.

Kuzuhisa, Y., 1979. Determination of water content in muscovites containing large amounts of fluorine by Karl Fischer titration after fusion with silicon dioxide. Anal. Chim. Acta 110, 233-243.

Maxwell, J.A., 1968. Rock and Mineral Analysis, Interscience, New York, pp. 217-224.

Mitchell, J.Jr., 1961. »Water», In I.M. Kolthoff and P.J. Elving (Eds.), Treatise on Analytical Chemistry, Vol. 2, Part II, Interscience, New York, 69-206.

Peck, L.C., 1964. Systematic Analysis of Silicates. U.S. Geol. Surv., Bull., 1170.

Potts, P.J., 1987. A Handbook of Silicate Rock Analysis. Glasgow, Blackie \& Sons Ltd, 70-75.

Pyper, J.W., 1985. The determination of moisture in solids. A selected review. Anal. Chim. Acta 170, 159-175.

Riley, J.P., 1958. Simultaneous determination of water and carbon dioxide in rocks and minerals. Analyst 83, 42-49.

Skinner, N.G., Brown, F.W., \& Flanagan, F.J., 1981. The $\mathrm{H}_{2} \mathrm{O}^{+}$Contents of Some Geochemical Standards Predicted by a Calibration Line. Geostand. Newslett. 5, 3-11.

Troll, G. \& Farzaneh, A., 1978. Determination of fluorine and total water in thirty-three international geochemical reference samples. Geostand. Newslett. 2, 43-47.

Volborth, A., 1969. Elemental Analysis in Geochemistry. Elsevier Publishing Company, Amsterdam, pp. 118-124.

Westrich, H.R., 1987. Determination of water in volcanic glasses by Karl-Fischer titration. Chem. Geol. 63, $335-340$.

Received October 18, 1989

Revision accepted January 16, 1990 